\title{
Richard Tregear, Co-founder of the Journal of Muscle Research and Cell Motility
}

\author{
Steven Baxter Marston ${ }^{1}[$
}

Received: 6 February 2021 / Accepted: 19 February 2021 / Published online: 11 March 2021

(c) The Author(s) 2021

Richard Tregear died 1st May 2020, he was 88 years old.

He will be remembered as a significant contributor to our understanding of muscle contraction, particularly in the 1960s and 1970s but more especially as a cofounder of The Journal of Muscle Research and Cell Motility.

Richard studied physics at Cambridge and after spells as a schoolteacher and as a researcher at Porton Down, he was picked by John Pringle to join his newly-formed ARC Unit of Insect Physiology in the Zoology Department of Oxford University. This talented group contained a potent mixture of physicsists, biologists, physiologists and biochemists that included Eric Newsholme, Belinda Bullard, Roger Abbot and Peter Brunet. The fundamental research done by this group exploited the unique properties of the fibrillar flight muscle of the giant water bug Lethocerus.

Richard's research contributions were seminal in many areas and include the first direct demonstration of stretchactivation of actomyosin ATPase (Rüegg and Tregear 1966) and the direct visualisation of rigor and relaxed crossbridges in muscle by EM and X-ray techniques (Miller and Tregear 1970; Reedy et al. 1965; Tregear and Miller 1969); this work was roughly contemporaneous with Hugh Huxley's studies but gained much less recognition.

He was a modest and very thoughtful man who revelled in scientific arguments; he was closely involved in the challenges and controversies of this exciting era of muscle research. He achieved much by asking questions and motivating others to find answers rather than as andividual experimenter. Amongst the research he instigated were the demonstration that the Myosin ADP.Pi complex, predicted by in vitro kinetics, was present in muscle (Marston and Tregear 1972), that substrate binding and mechanical output were directly and reversibly coupled (Marston et al. 1979), that the proportion of myosin to actin varied between muscle

Steven Baxter Marston

s.marston@imperial.ac.uk

1 Imperial College London, London, UK types and was directly related to the way the filaments were arranged (Tregear and Squire 1973) (this was a pioneering quantitative gel electrophoresis study) and he made the first $\mathrm{X}$-ray diffraction measurements of the temporal relationship of crossbridge movement to muscle force by taking advantage of the cyclical nature of stretch-activated Lethocerus muscle (Armitage et al. 1975) (again a pioneering study which is all the more remarkable since the binning of each contractile cycle into eight segments and its aggregation over hours of contraction needed to get a signal was controlled by a suitcase sized-PDP10 computer with just $8 \mathrm{~K}$ of RAM and no hard disk!). On a sabbatical in San Francisco he published the seminal theoretical paper on fluorescence polarisation in muscle (Tregear and Mendelson 1975).

Richard was also a passionate educator. His animated film “What Makes Muscle Pull?" was made as long ago as 1971 (Tregear 1971) yet it remains a classic_-and still correctexposition of crossbridge cycling to this day. Although he rarely spoke at scientific meetings and he had only a few PhD students, he was a great promoter of scientific discussions in less formal situations. He was involved in reviving the Muscle Club Dinners in the 1970s and promoting the Alternative Muscle Club for student and postdocs, founded by his student, Maxine Clarke in 1980. He much preferred the small meetings and especially the Alpbach Workshops where his incisive questioning would catch unsuspecting postdocs off-guard and puncture the overambitious theorising of their supervisors. They could end up being signed up as collaborators by the end of the meeting.

His enthusiasm for scientific discourse culminated in the founding of the Journal of Muscle Research and Cell Motility with Chris Ashley in 1980. The first issue editorial starts with a passage that is quintessential Richard Tregear "This JournaI is intended for everyone interested in the problems of biological motion, whether in proteins or in plants. We believe that there are enough interests in common throughout this range of work to justify pulling all of them together in one place. The contents of the first issue confirm our prejudice-the range is enormous, the enthusiasm common to all. “ 
Richard Tregear at Alpbach, March 1974; photo by Clive Bagshaw

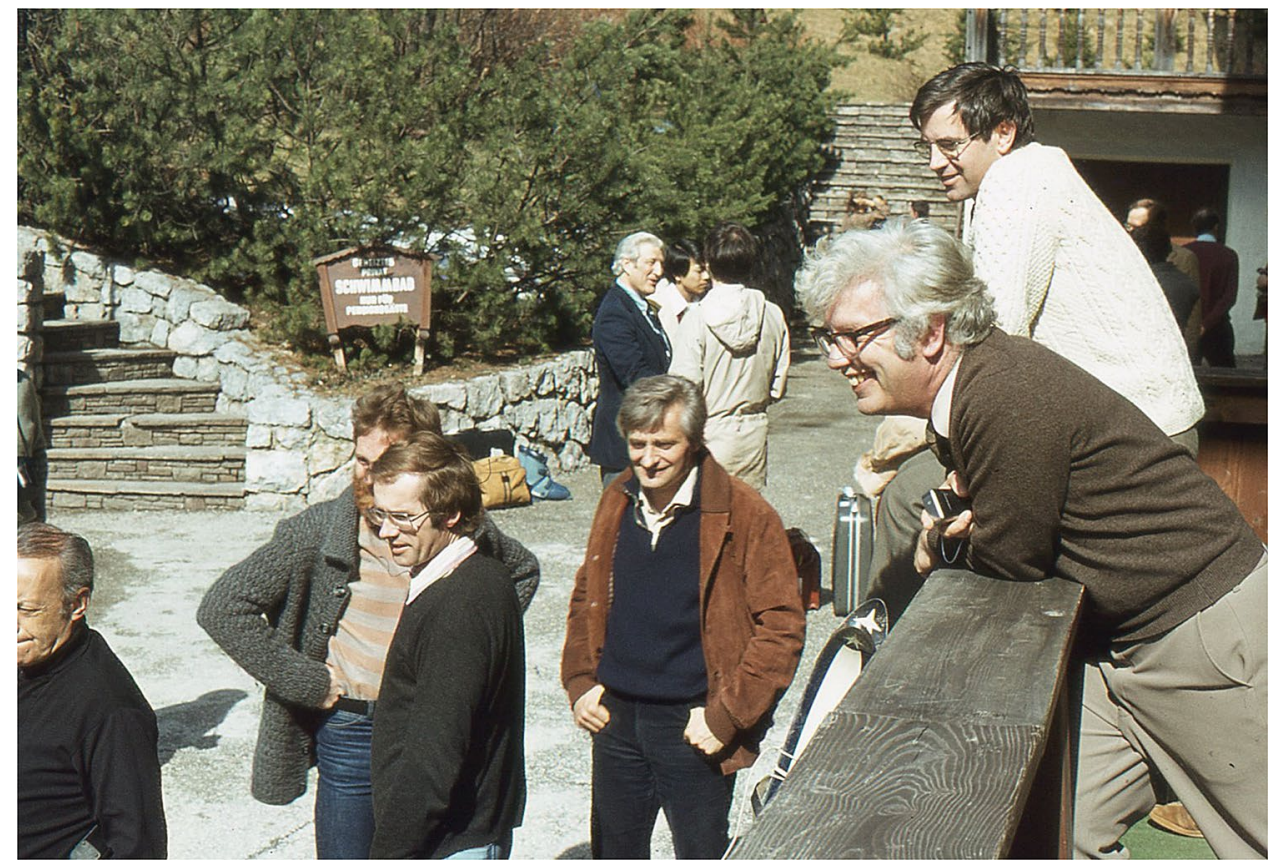

When John Pringle retired in 1985, the Oxford ARC unit closed and Richard moved to the ARC Institute at Babraham. Here he had fewer opportunities for muscle research. He took early retirement and became a 'gentleman scientist', travelling to laboratories near and far (especially Cambridge and Duke) for experimentation and debate until he was well into his 70s (Tregear et al. 2004; Wu et al. 2010).

We shall remember his ideas, style and enthusiasm. The Journal of Muscle Research he created has prospered for 40 years now and is a fitting legacy.

Open Access This article is licensed under a Creative Commons Attribution 4.0 International License, which permits use, sharing, adaptation, distribution and reproduction in any medium or format, as long as you give appropriate credit to the original author(s) and the source, provide a link to the Creative Commons licence, and indicate if changes were made. The images or other third party material in this article are included in the article's Creative Commons licence, unless indicated otherwise in a credit line to the material. If material is not included in the article's Creative Commons licence and your intended use is not permitted by statutory regulation or exceeds the permitted use, you will need to obtain permission directly from the copyright holder. To view a copy of this licence, visit http://creativecommons.org/licenses/by/4.0/.

\section{References}

Armitage PM, Tregear RT, Miller A (1975) Effect of activation by calcium on X-ray-diffraction pattern from insect flight-muscle. J Mol Biol 92:39-53. https://doi.org/10.1016/0022-2836(75)90090-х

Marston SB, Tregear RT (1972) Evidence for a complex between myosin and ADP in relaxed muscle fibres. Nat New Biol 235:23-24. https://doi.org/10.1038/newbio235023a0
Marston SB, Tregear RT, Roger CD, Clarke ML (1979) Coupling between the enzymic site of myosin and the mechanical output of muscle. J Mol Biol 128:111-126. https://doi.org/10.1016/00222836(79)90121-9

Miller A, Tregear RT (1970) Evidence concerning crossbridge attachment during muscle contraction. Nature 226:1060-2000. https:// doi.org/10.1038/2261060a0

Reedy MK, Holmes KC, Tregear RT (1965) Induced changes in orientation of the cross-bridges of glycerinated insect flight muscle. Nature 207:1276-1280. https://doi.org/10.1038/2071276a0

Rüegg JC, Tregear RT (1966) Mechanical factors affecting the ATPase activity of glycerol-extracted insect fibrillar flight muscle. Proc $\mathrm{R}$ Soc Lond B 165:497-512. https://doi.org/10.1098/rspb.1966.0080

Tregear RT (1971) Movie "What makes Muscle Pull?" Wiley, New York. $16 \mathrm{~mm}$ film: a digital transcript can be found at https://www. dropbox.com/s/1fbucjqsomg $811 \mathrm{u} /$ Tregear\%20What\%20Mak es\%20Muscle\%20Pull\%3F\%201971.mp4?dl=0

Tregear RT, Mendelson RA (1975) Polarization from a helix of fluorophores and its relation to that obtained from muscle. Biophys J 15:455-467. https://doi.org/10.1016/S0006-3495(75)85830-9

Tregear RT, Miller A (1969) Evidence of crossbridge movement during contraction of insect flight muscle. Nature 222:1184-1185. https ://doi.org/10.1038/2221184a0

Tregear RT, Squire JM (1973) Myosin content and filament structure in smooth and striated-muscle. J Mol Biol 77:279. https://doi. org/10.1016/0022-2836(73)90336-7

Tregear RT et al (2004) Cross-bridge number, position, and angle in target zones of cryofixed isometrically active insect flight muscle. Biophys J 86:3009-3019. https://doi.org/10.1016/S0006 $-3495(04) 74350-7$

Wu S et al (2010) Electron tomography of cryofixed, isometrically contracting insect flight muscle reveals novel actin-myosin interactions. PLoS ONE. https://doi.org/10.1371/journal.pone.0012643

Publisher's Note Springer Nature remains neutral with regard to jurisdictional claims in published maps and institutional affiliations. 